\title{
From Feedback Seeking to Psychological Attachment, the Mediating Role of Adaptive Performance in Perceived Obstruction Context - CORRIGENDUM
}

\author{
Guillaume R. M. Déprez, Nicolas Bazine, Léa Fréour, Marco Peña-Jimenez, Nicola Cangialosi and \\ Adalgisa Battistelli
}

https://doi.org/10.1017/SJP.2021.1, Published online by Cambridge University Press, 05 February 2021

Keywords: adaptive performance, feedback-seeking, perceived organizational obstruction, proactivity, psychological Attachment

This article was published in The Spanish Journal of Psychology with an error in the author's name, the authors' correct name is Guillaume R. M. Déprez. This has now been corrected online and in the article.

The authors and publishers apologise for this error.

\section{Reference}

Déprez, G. R. M., Bazine, N., Fréour, L., Peña-Jimenez, M., Cangialosi, N., \& Battistelli, A. (2021). From Feedback Seeking to Psychological Attachment, the Mediating Role of Adaptive Performance in Perceived Obstruction Context. The Spanish Journal of Psychology, 24, E1. doi:10.1017/SJP.2021.1 